\title{
Chrzcielnice i kropielnice parafii toruńskich datowane na okres od XIII do XVIII wieku
}

Mariola Gajewska Toruń

Niniejszy artykuł poświęcony jest chrzcielnicom i kropielnicom z kościołów parafii toruńskich, datowanym na okres od XIII do XVIII w., oraz ich niektórym analogiom $\mathrm{z}$ terenu dawnego i dzisiejszego dekanatu toruńskiego. Wśród przedstawionych zabytków znajdują się także obiekt uzyskany w wyniku badań archeologicznych oraz zabytek znajdujący się obecnie w Muzeum Okręgowym w Toruniu.

Zbiór chrzcielnic i kropielnic z kościołów parafii Torunia, które zostały ujęte $\mathrm{w}$ niniejszym artykule, otwiera zabytek datowany na około XIII w. Chrystianizacja ziemi chełmińskiej zaczęła się wprawdzie tuż po przyjęciu chrztu przez Mieszka I, jednakże to wiek XIII charakteryzował się znacznym rozrostem sieci parafialnej, głównie z inicjatywy zakonu krzyżackiego. Jednym z typów kamiennych chrzcielnic występujących na tym terenie są średniowieczne chrzcielnice wykonane $\mathrm{z}$ wapienia, licznie spotykane na Niżu Bałtyckim, a w szczególności w państwie krzyżackim. Chrzcielnice te pochodzą z Gotlandii, wyspy Morza Bałtyckiego, i docierały na te tereny prawdopodobnie już od trzeciej ćwierci XIII w. dzięki wędrownym wykwalifikowanym rzeźbiarzomkamieniarzom - lapicydom ${ }^{1}$. Ich duże nagromadzenie $\mathrm{w}$ pobliżu Torunia związane jest zapewne $\mathrm{z}$ faktem, iż miasto było $\mathrm{w}$ tym okresie naj-

${ }^{1}$ J. Kruszelnicka, Zbiory gotyckiej rzeźby i malarstwa Muzeum Okręgowego w Toruniu, Toruń 1968, s. 47-48. 
potężniejszym członkiem Hanzy w państwie krzyżackim² ${ }^{2}$ Dokładne datowanie tych chrzcielnic jest kwestią szczególnie problematyczną, ponieważ cechują się one wyjątkowym konserwatyzmem formy artystycznej.

Jedna ze starszych mis tego typu została odkryta podczas badań archeologicznych prowadzonych przy kościele św. Jakuba w Toruniu w 2008 r. Badania organizowane były w tym miejscu w pięciu sezonach (poczynając od 2008 r., po 2010, 2011, 2012 i 2013); opracowanie z ostatniego, z 2013 r., nie zostało jeszcze opublikowane. W czasie czterech pierwszych sezonów założono łącznie jedenaście wykopów i trzy sondaże, skupiono się na obszarze wokół prezbiterium kościoła oraz przy jego południowej stronie w pobliżu dawnego przyklasztornego budynku. Celem badań było wstępne rozpoznanie początków Nowego Miasta i kościoła, historii klasztoru cysterek-benedyktynek oraz zbadanie nowomiejskiego cmentarza ${ }^{4}$. W czasie badań odkryto m.in. XIII/XIV-wieczną misę chrzcielną, naczynia ceramiczne (wydobyte z najstarszej jednostki kulturowej - znad calca), krzyżackie denary brakteatowe (znalezisko najstarsze i stosunkowo nieliczne), XVIIwieczną kameryzowaną broszę w kształcie rozety, wykonaną ze srebrnej blachy, i inne znaleziska ruchome, takie jak wędzidła końskie, kamienne formy odlewnicze, fragmenty kościanych grzebieni i zawieszek czy brązowe okucie końcówki pasa ${ }^{5}$. Do znalezisk należą także liczne elementy wyposażenia trumien, fragmenty kamionki łużyckiej. Odkrycia datowane na XIX i początek XX w. to m.in. fajki złożone, pojedyncze monety (fenigi z 1876 r.), szklana butelka z niemieckim napisem oraz zbiór krucyfiksów zlokalizowanych wokół zakrystii ${ }^{6}$. Z badań cmentarza pochodzi „wyposażenie grobowe”, na które składają się liczne wiązki drucików, łańcuszki, szpilki krawieckie, fragmenty

\footnotetext{
${ }^{2}$ Ibid., s. 48.

${ }^{3}$ Ibid., s. 47.

${ }^{4}$ K. Sulkowska-Tuszyńska, Primum non nocere! O archeologicznych badaniach wokót toruńskiego kościoła św. Jakuba, [w:] Studia i materiaty z dziedzictwa kulturowego Torunia i regionu, t.1: Stare i nowe dziedzictwo Torunia, red. J. Raczkowski, Toruń 2013, s. 58

${ }^{5}$ Ibid., s. 61.

${ }^{6}$ Ibid., s. 62.
} 
wstążek, tkanin, kościane guziki, haftki do ubrań, paciorki oraz przede wszystkim różnego rodzaju wianki, w których grzebano niektórych zmarłych $^{7}$. Osobny problem badawczy stanowiło odkrycie, rozpoznanie i interpretacja fundamentów kościoła $\mathrm{w}$ związku $\mathrm{z}$ zakłóceniem relacji stratyfikacyjnej: fundament - bryła prezbiterium, co może być łączone $\mathrm{z}$ tezą dotyczącą istnienia w tym miejscu innej, starszej świątyni wzniesionej w XIII w. bądź ze zmianą koncepcji budowy kościoła przez architekta 8 .

Odkryty w 2008 r. przy kościele św. Jakuba fragment gotlandzkiej misy chrzcielnej (ryc. 1) zalegał wraz z fragmentami ceramiki, dachówek, cegieł i naczyń przed bocznym portalem prezbiterialnym, obok wschodniej ściany nawy południowej kościoła, w wytyczonym w tym miejscu wykopie W-2/08. Przyjmuje się, iż zabytek ten był najprawdopodobniej porzucony w czasie jednego z remontów świątyni w XIX w. ${ }^{9}$ Zachowana $\mathrm{w}$ czterdziestu procentach misa ma kształt ośmioboku ${ }^{10}$, lecz jej wysokość i średnica są jedynie szacowane. Jej spód jest płaski, dlatego można przypuszczać, że pierwotnie miała podstawę. Oprócz materiału, z jakiego została wykonana, dowodem jej gotlandzkiego pochodzenia jest także relief zachowany na czterech fragmentach ścian. Przedstawia on kroczące lwy, po jednym na ściankach, które z kolei oddzielone są od siebie lekko wypukłym żebrem, z widocznym rozgałęzieniem, tworząc tym samym coś na kształt arkady ${ }^{11}$. Ciekawym i zastanawiającym jest fakt, że nie wszystkie zachowane ścianki są zdobione, co może oznaczać, że misa nie była wykończona, a tym samym i użytkowana. Być może, przypadkowo, podczas tworzenia po prostu pękła, a następnie została porzucona wraz z gruzem ceramicznym, w którym

\footnotetext{
${ }^{7}$ Ibid., s. 62.

${ }^{8}$ Ibid., s. 64 .

${ }^{9}$ K. Sulkowska-Tuszyńska, Kamienna misa chrzcielna odkryta przy kościele św. Jakuba w Toruniu, Slavia Antiqua, t. LIII, Toruń 2012, s. 192.

${ }^{10}$ Cyfra osiem w symbolice chrześcijańskiej postrzegana jest jako doskonałość, oznacza dzień zmartwychwstania Chrystusa. Ośmioboczne w rzucie były baptysteria starochrześcijańskie, a gdy już ich nie budowano, kształt ten z czasem nadawano formom chrzcielnic (D. Forstner, Świat symboliki chrześcijańskiej, Warszawa 1990, s. 4849, 61).

${ }^{11}$ Takie połączenie motywu kroczącego pod arkadą zwierzęcia występuje również na chrzcielnicy z Grudziądza.
} 


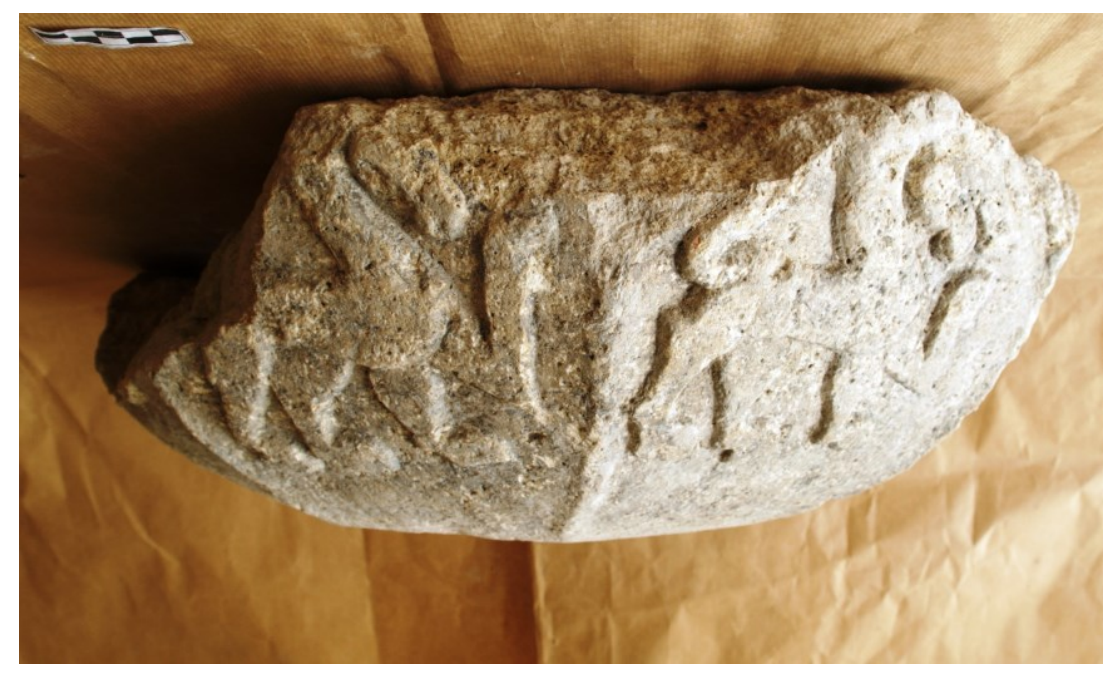

Ryc. 1. Toruń, kościół św. Jakuba, fragment misy chrzcielnej (fot. M. Kołyszko)

ją znaleziono. Misa musiała być zatem wykonana z importowanego kamienia przez artystę obeznanego ze zdobnictwem gotlandzkim. $Z$ kolei fakt zalegania misy w warstwie XIX-wiecznej może jednak świadczyć o tym, że była ona do tego czasu użytkowana, a więc wykończona.

$\mathrm{Z}$ terenów ziemi chełmińskiej znane są również inne chrzcielnice gotlandzkie. Jedną z nich jest chrzcielnica z kościoła św. Jana Chrzciciela w Górsku, datowana na początek XIV w. Jej czasza, podobnie jak czasza chrzcielnicy z kościoła św. Jakuba, także jest ośmioboczna, a zdobienie, znacznie bardziej urozmaicone, przedstawia walki ludzi z fantastycznymi zwierzętami, gdzie każde zwierzę okalane jest od góry półkolistą arkadą. Motyw ten zajmuje pięć z ośmiu ścian czaszy, pozostałe trzy natomiast wypełnia mniej lub bardziej złożone przedstawienie roślinne, niemające specjalnego znaczenia. Takie rozwiązanie mogło być zastosowane ze względu na umiejscowienie chrzcielnicy pod ścianą. Misa stoi na kamiennej ośmiobocznej podstawie wykonanej w $1984 \mathrm{r}^{12}$

${ }^{12}$ A. Walczyński, Górsk i okolice od prehistorii do połowy XX wieku, Toruń 2005, s. 26 . 
Chrzcielnica stała początkowo w dawnym katolickim kościele w Starym Toruniu. Tamtejszy kościół zdewastowano jednak w XVI w., po czym chrzcielnica trafiła do świątyni w Górsku ${ }^{13}$. Na temat jej początków istnieje legenda mówiąca o tym, że podobno chrzcielnica była użytkowana jako żłób w jednym z gospodarstw chłopskich ${ }^{14}$. Od 1694 r. na stropie kościoła widnieje malowidło $\mathrm{z}$ wizerunkiem chrzcielnicy przypominającej tu omawianą. W każdym razie namalowana podobizna ma, tak jak oryginał, ośmioboczną czaszę, różni się natomiast przedstawieniem wojownika, które zamiast na czaszy widnieje na stopie $^{15}$. W 1727 r. do chrzcielnicy dodano drewnianą przykrywę; pierwotnie na jej zwieńczeniu znajdowała się grupa rzeźbiarska przedstawiająca scenę chrztu w Jordanie. Obecnie nie pełni ona swojej funkcji. Jak się okazało w 2003 r., przykrywę przechowywano w pomieszczeniach gospodarczych, skąd od lat siedemdziesiątych XX w. była wyjmowana w każde święta Bożego Narodzenia, by służyć jako podstawa pod choinkę ${ }^{16}$.

Trzecim zabytkiem omawianego typu jest chrzcielnica z nieistniejącego już XIII-wiecznego kościoła świętych Wita i Modesta w Grębocinie. Dziś chrzcielnica znajduje się w Muzeum Okręgowym w Toruniu. Obiekt ten różni się nieco od poprzednio omawianych, również gotlandzkich. Jego czasza jest okrągła w rzucie i nie ma już tak urozmaiconego zdobienia. Jedynym motywem okalającym czaszę jest motyw powtarzających się arkad. Poza tym misa ma gładki trzon i stopę. Jeszcze dziś na zabytku widoczne są ślady pierwotnej polichromii. Czasza wraz ze stopą była bowiem malowana na niebiesko i biało, trzon zaś tylko na biało. Datowanie tej chrzcielnicy jest równie problematyczne jak datowanie wszystkich gotlandzkich chrzcielnic. Mylne może być stwierdzenie, jakoby prostota zdobnictwa grębocińskiej misy była podstawą do wydatowania jej na wiek XIII. Takie rozwiązanie stylistyczne może przecież wynikać z charakteru zlecenia danego arty-

\footnotetext{
${ }^{13}$ Diecezja toruńska. Historia i teraźniejszość, t. 15,16,17, Dekanaty toruńskie - I, II i III, pod red. S. Kardasza, Toruń 1995, s. 199.

${ }^{14}$ A. Walczyński, op. cit., s. 119.

${ }^{15}$ Ibid., s. 119.

${ }^{16}$ Ibid., s. 119.
} 
ście. Brak wystarczających funduszy zmuszał kościół do zamówienia mniej kosztownej, a tym samym ubogo zdobionej chrzcielnicy ${ }^{17}$. Takie zamówienie mogło zostać złożone zaraz po wybudowaniu kościoła, czyli na początku XIV w. Jednakże ze względu na to, iż chrzcielnica jest prawdopodobnie importem gotlandzkim (a na pewno wyrobem z wapienia gotlandzkiego), co wiąże się z obecnością zakonu krzyżackiego oraz z kontaktami miast pruskich z Gotlandią, nie można datować jej na okres wcześniejszy niż na trzecią ćwierć XIV w. ${ }^{18}$ Mogła także zostać wykonana w XVI w., kiedy to włożono do niej norymberską misę chrzcielną. Teza ta została poparta dodatkowo przez Janinę Kruszelnicką argumentem o istnieniu analogicznej misy w Rogowie, z podobnie prostym zdobieniem i formą, datowanej na XVI w. ${ }^{19}$ Jednak w przypadku chrzcielnicy rogowskiej późniejsza literatura określała czas jej powstania na XIV w., a więc taki sam, jak pozostałych opisanych tu mis gotlandzkich ${ }^{20}$. Dodatkowo relief chrzcielnicy z Rogowa, poza rytmicznie powtarzającymi się ostrołukowymi arkadami okalającymi czaszę, ma także zdobienie $\mathrm{w}$ formie rozetki znajdującej się $\mathrm{w}$ połowie wysokości każdego filaru. Motyw na pozór się powtarza, jednak przyglądając się bliżej dostrzegamy, iż górne części arkad mają odmienne przedstawienia motywu roślinnego. Do tej chrzcielnicy, podobnie jak w przypadku poprzednich, również dodano drewnianą przykrywę w duchu protestanckiej liturgii chrztu, zwieńczoną sceną chrztu w Jordanie. Karta ewidencyjna tej chrzcielnicy zawiera także informację o tym, że na misie była pierwotnie polichromia, co potwierdzić może z kolei przypadek chrzcielnicy z Grębocina.

Znane są jeszcze chrzcielnice typu gotlandzkiego z kościołów w Grudziądzu (ryc. 2), Elblągu, Chełmnie i Królewcu ${ }^{21}$ oraz z samej wyspy Gotlandii - chrzcielnice z Ystad, Frojel czy Falsterbo.

Obok kamiennych chrzcielnic z Gotlandii, na terenie Torunia znane są również misy wykonane przez lokalnych rzemieślników. Jedną z nich

\footnotetext{
${ }^{17}$ J. Kruszelnicka, op. cit., s. 47.

${ }^{18}$ Ibid., s. 48.

${ }^{19}$ Ibid., s. 48 .

${ }^{20}$ T. Chrzanowski, M. Kornecki, Katalog zabytków sztuki w Polsce, t. XI, z.16, Powiat toruński, Warszawa 1972, s. 63; Diecezja toruńska, s. 238.

${ }^{21}$ J. Kruszelnicka, op. cit., s. 47.
} 


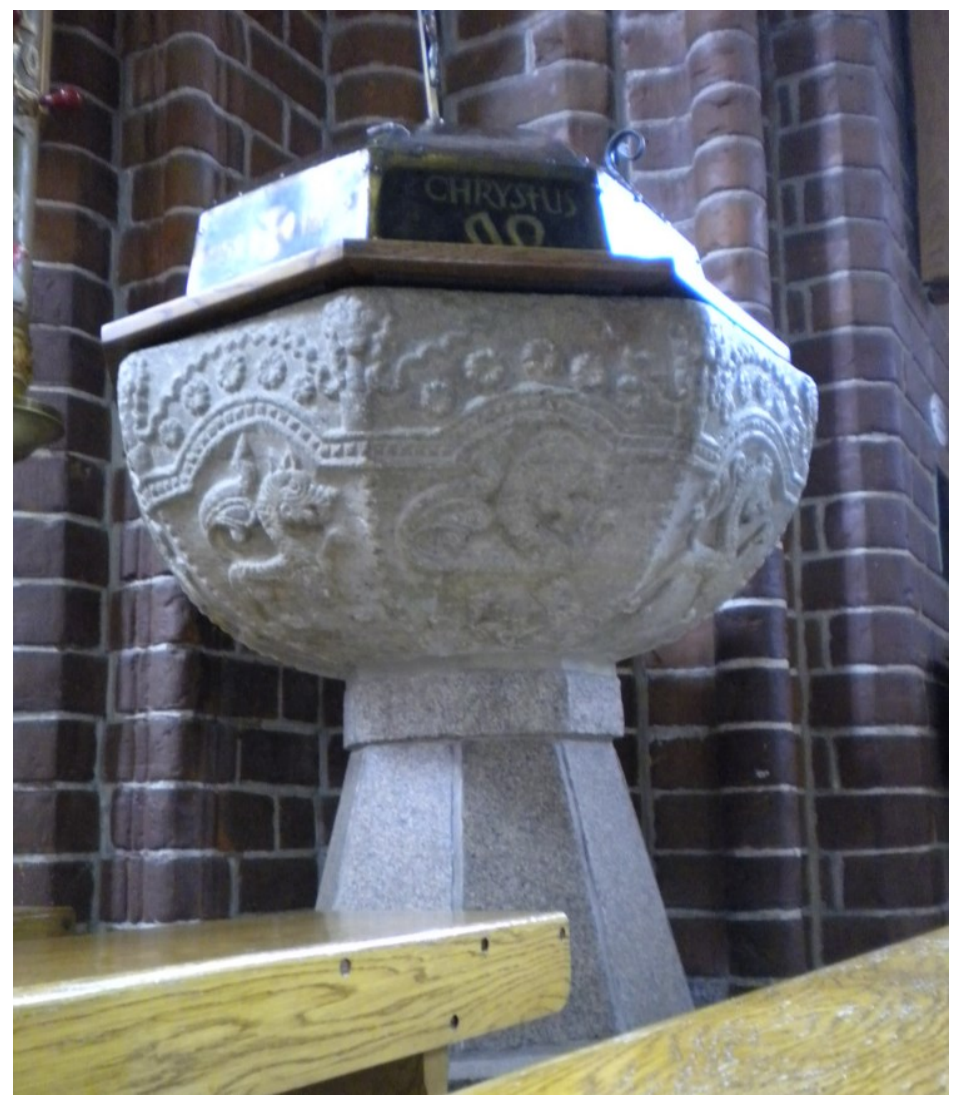

Ryc. 2. Grudziądz, kościół św. Mikołaja, chrzcielnica (fot. M. Gajewska)

jest misa chrzcielna pełniąca niegdyś także funkcję kropielnicy, znajdująca się w kościele Podwyższenia Krzyża Świętego w Kaszczorku (ryc. 3). Obiekt ten według karty ewidencyjnej datowany jest już jednak na XV-XVI w.; wyciosany jest $\mathrm{z}$ jednego kamienia, ma nieregularny kształt i nie jest zdobiony. Pełni dziś funkcję chrzcielnicy, ponieważ wcześniejsza, znajdująca się w kościele, drewniana, prawdopo- 


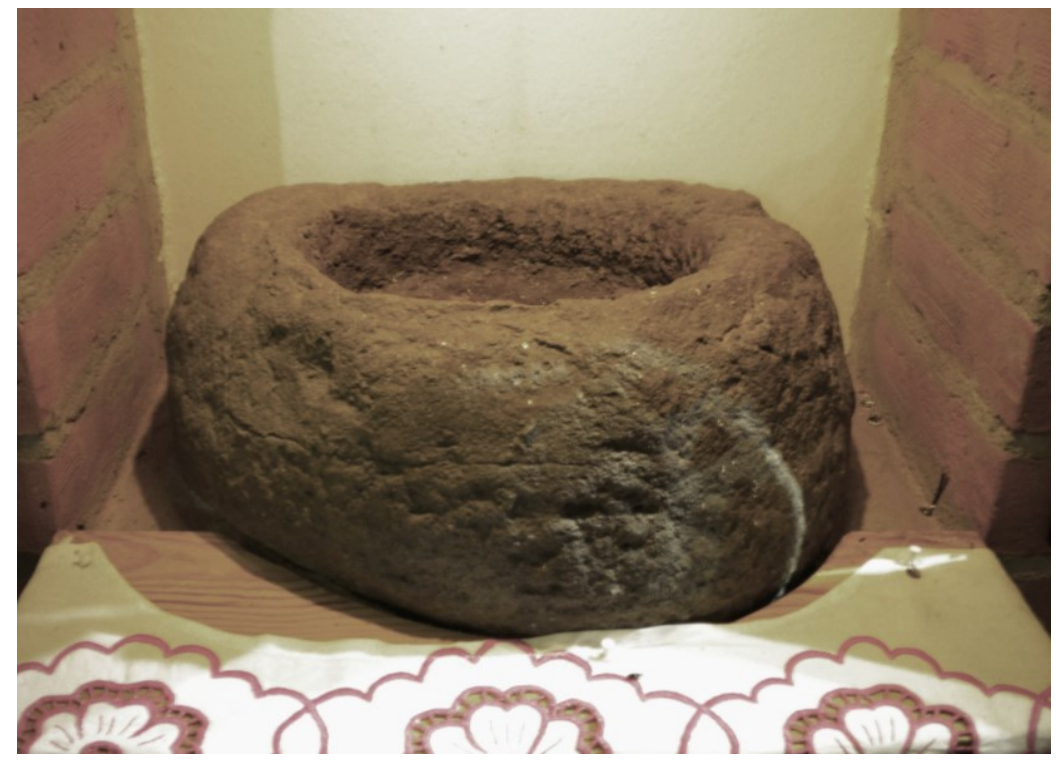

Ryc. 3. Toruń (Kaszczorek), kościół Podwyższenia Krzyża Świętego, chrzcielnica (fot. M. Gajewska)

dobnie barokowa ${ }^{22}$, spłonęła w pożarze w 1966 r. $^{23}$ Dziś, wchodząc do kościoła, chrzcielnicę tę można łatwo pominąć ze względu na umieszczenie jej w dość oryginalnej nowoczesnej zabudowie, wmurowanej w południową ścianę prezbiterium, mającej na zwieńczeniu coś w rodzaju szafki podświetlanej od środka, otwieranej na potrzeby chrztu. Analogiczne dwa zabytki znajdujemy także w pobliskim Przecznie, w kościele Krzyża Świętego. Tamtejsza, wyciosana również z jednego kamienia chrzcielnica stała niegdyś w kruchcie zachodniej, jednak sądzi się, że jej pierwotne miejsce znajdowało się tuż przy ołtarzu w prezbi-

\footnotetext{
${ }^{22}$ F. K. Okroy, Kościoły Diecezji Chetmińskiej. Dekanat Toruński, Orędownik Diecezji Chełmińskiej, 1959, nr 7-8, s. 249.

${ }^{23}$ Diecezja toruńska, s. 242
} 
terium $^{24}$. Brak jednak informacji dotyczących okoliczności jej przeniesienia. Dziś chrzcielnica stoi w części prezbiterialnej kościoła na specjalnie dla niej zbudowanym otynkowanym cokole, zwieńczonym pasem nowożytnej cegły. $Z$ tego kościoła pochodzi także jeszcze jedna kropielnica, różniąca się jedynie kształtem kamienia, w którym wyżłobiono zbiornik na wodę święconą. Podobnie jak wcześniejszą misę i tę trudno jest wydatować konserwatorom ze względu na brak jakichkolwiek stylowych cech. Datowanie widniejące na kartach ewidencyjnych obu mis wskazuje okres średniowiecza. Jednakże biorąc pod uwagę czas wybudowania świątyni oraz bardzo prymitywny, zapewne szybki sposób wykonania mis można by się pokusić o stwierdzenie, iż powstały one w XIII/XIV w. W kościołach, które pełniły funkcję parafii, a ich prezbiterium na początku XIV w. funkcjonowało, chrzcielnica była potrzebna od samego początku ${ }^{25}$. Takie nieregularne misy chrzcielne znajdują się także przy kościele Wniebowzięcia NMP w Dźwierznie. Znacznie większe od wcześniej wspomnianych i marmurowe stoją na zewnątrz świątyni po jej południowej stronie, sukcesywnie niszczejąc pod wpływem warunków atmosferycznych i biologicznych. Z kart ewidencyjnych wynika, że były one pierwotnie ufundowane przez inicjatora kościoła (kościół wybudowano w XIII/XIV w., a budulcem był przede wszystkim kamień polny ${ }^{26}$ ). Z kolei przykłady mis o tych samych cechach co misa $\mathrm{z}$ kościoła $w$ Kaszczorku znamy z kościoła św. Marcina w pobliskim Czarnowie oraz z kościoła św. Jana Chrzciciela w Świerczynkach. Obydwie usadowione w kruchtach pełnią dziś funkcję kropielnic.

Jeszcze jeden przykład kamiennego zabytku w Toruniu stanowi kropielnica z kościoła Wniebowzięcia NMP, o której nie ma jednak w literaturze nawet małej wzmianki. Kropielnica jest bardzo nietypowa, ma ośmioboczną czaszę i umieszczona jest na murowanej nieregularnej stopie wmurowanej częściowo w ścianę, przy której się znajduje.

\footnotetext{
${ }^{24}$ K. Sulkowska-Tuszyńska, Prezbiterium średniowiecznego kościoła p.w. Podwyższenia Krzyża Świętego w Przecznie koło Torunia. Ustalenia archeologa, [w:] Gotycka architektura sakralna, red. T. Janiak, Gniezno 2014, ss.15.

${ }^{25}$ Zob. uwagi o przestrzeni sakralnej kościoła w XIV w. K. Sulkowska-Tuszyńska, Prezbiterium średniowiecznego kościoła.

${ }^{26}$ T. Chrzanowski, M. Kornecki, op. cit., s. 29.
} 
Można się jedynie domyślać, że została wykonana najprawdopodobniej w średniowieczu.

Z okresu średniowiecznego znane są także chrzcielnice wykonane $\mathrm{z}$ innego niż kamień materiału - z metalu. $Z$ liczby zabytków tego typu na omawianym obszarze oraz $\mathrm{z}$ tego, w jakich świątyniach się znajdują, można by wnioskować, że był to ekskluzywny, jak na tamte czasy, materiał. Jedną $z$ dwóch zachowanych do dziś takich mis jest trzynastowieczna chrzcielnica $\mathrm{z}$ kościoła świętojańskiego w Toruniu. Zabytek ten stanowi jeden $\mathrm{z}$ ważniejszych obiektów sakralnych Torunia, a przy tym także jeden $z$ najstarszych wyrobów średniowiecznego ludwisarstwa na terenie państwa zakonu krzyżackiego ${ }^{27}$. Obiekt znajduje się obecnie w Kaplicy Kopernika i składa się z brązowej czaszy umocowanej zaprawą na kamiennej podstawie $\mathrm{z}$ profilowaną stopą ${ }^{28}$, która najprawdopodobniej została dodana dopiero około $1881 \mathrm{r} .{ }^{29}$ Wcześniej chrzcielnica znajdowała się zapewne, od XVI w., przy pierwszym od strony wschodniej filarze międzynawowym po stronie południowej. Tam, naprzeciw ołtarza św. Anny, miała własne ogrodzenie wydzielające granice wewnątrzkościelnego baptysterium ${ }^{30}$. W tym okresie czasza była również przemalowana na biało. Dodatkowy element stanowiły kwiaty dekorujące arkadki, a napis widniejący na dolnym pasie misy powleczony był czarną farbą ${ }^{31}$.

\footnotetext{
${ }^{27}$ M. Jakubek-Raczkowska, Trzynastowieczna chrzcielnica z Kaplicy Kopernika w kościele p.w. św. Jana Chrzciciela i św. Jana Ewangelisty w Toruniu, [w:] Dzieje i skarby kościoła świętojańskiego w Toruniu, red. K. Kluczwajd, M. Woźniak, Toruń 2002, s. 237.

${ }^{28}$ Metalowe chrzcielnice z XIII w. miały zazwyczaj formę kotła wspartego na trzech lub czterech podporach, w tym przypadku jednak chrzcielnica najprawdopodobniej została wykonana na wzór powszechnych wówczas w tym regionie kamiennych chrzcielnic, a także ze względu na niewielkie doświadczenie odlewników dzwonów w produkcji chrzcielnic (M. Jakubek-Raczkowska, op. cit., s. 254-255).

${ }^{29}$ Fakt ten potwierdzają wizerunki chrzcielnicy jako samodzielnej misy, reprodukcji Aleksandra Przezdzieckiego, Edwarda Rastawieckiego oraz Wilhelma Kolberga (M. Jakubek-Raczkowska, op. cit., s. 238).

${ }^{30}$ J. Domasłowski, Wyposażenie wnętrza, [w:] Bazylika katedralna Świętych Janów w Toruniu, red. M. Biskup, Torun 2003, s. 156.

${ }^{31}$ M. Jakubek-Raczkowska, op. cit., s. 238-239.
} 
Technika, jaką wykonano misę, jest techniką powszechnie stosowaną w średniowieczu od wieku XII, wykorzystywaną przy odlewie dzwonów (ryc. 4), czyli wytopu w glinianej formie ${ }^{32}$. Nie do końca znany jest warsztat, w którym chrzcielnicę odlano, jednakże przyglądając się jej bliżej można zauważyć defekty techniczne powierzchni świadczące o jego niskim poziomie. Metal, z jakiego została wykonana, jest twardy i dźwięczny, co jest typową cechą dzwonów i jednocześnie wskazuje na odlewnika dzwonów jako autora świętojańskiej chrzcielnicy $^{33}{ }^{34}$. Za taką hipotezą przemawia także sposób zdobienia dwiema wypukłymi obręczami oraz nietypowe dolne (bliższe zwężającej się części misy) umieszczenie pasa inskrypcji, spotykane przy dekorowaniu dzwonów w XIII i XIV w. ${ }^{35}$ Tak zdobione chrzcielnice, oprócz świętojańskiej, nie są znane.

Jednym $\mathrm{z}$ większych problemów badaczy jest nierozszyfrowana dotąd inskrypcja $\mathrm{z}$ owego dolnego pasa misy. W związku z tą kwestią powstało kilka propozycji dotyczących charakteru napisu oraz jego thumaczenia. Wielu badaczy upatrywało w nim cechy pisma runicznego, greckiego, starosłowiańskiego głagolickiego (w konsekwencji czego przesuwano czas powstania obiektu na XIII czy XII w.) czy cyrylicy $^{36}$. Według Bernharda Schmida, znawcy m.in. średniowiecznej sztuki pomorskiej, forma znaków wskazuje na połowę XIV w. ${ }^{37}$ Jeśli zaś mowa o interpretacji treści, to w 1850 r. Jakub Kucharski odczytał inskrypcję następująco: $Z$ DIABOEY $W$ LEWO, IESUS GOSPODCHCE ZLEWAC CIEBIE WODA TA I ZYWOT WODA TA ZDROWY PODAJE LUDOWI. Propozycję tę odrzucono, argumentując, jakoby była wynikiem niedokładnego przerysu liter $^{38}$, w dodatku w inskrypcji nie ma żadnych odstępów pomiędzy wyrazami, przerywników w postaci

\footnotetext{
${ }^{32}$ Ibid., s. 239.

${ }^{33} \mathrm{~W}$ średniowieczu często zlecano odlewnikom dzwonów wykonywanie chrzcielnic ze względu na ich doświadczenie $\mathrm{w}$ obchodzeniu się $\mathrm{z}$ dużymi masami metalu (M. Jakubek-Raczkowska, op. cit., s. 239).

${ }^{34}$ M. Jakubek-Raczkowska, op. cit., s. 239.

${ }^{35}$ Ibid., s. 239-243.

${ }^{36}$ Ibid., s. 246.

${ }^{37}$ J. Domasłowski, op. cit., s. 156.

${ }^{38}$ M. Jakubek-Raczkowska, op. cit., s. 246.
} 


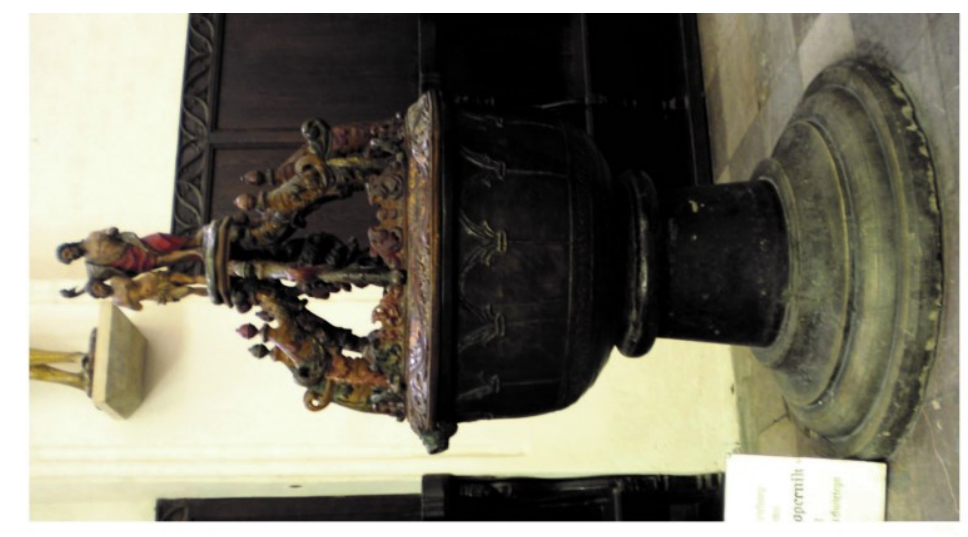

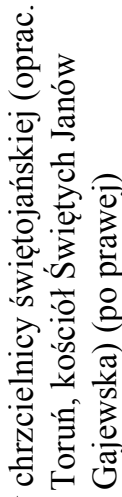

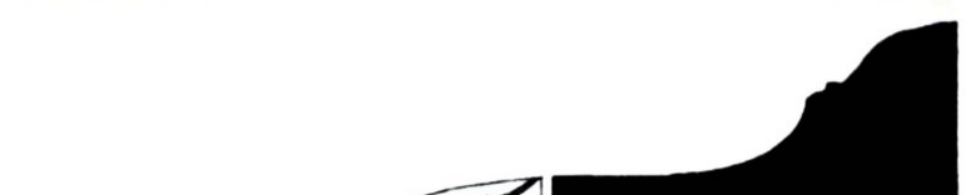

令亡

엉 훙

릉요

矛

감

过

品

ब

สิ

范

D

을 웜

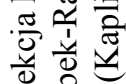

늘

ㄷ

¿

ฉ্ 
np. rozetek, a dodatkowo występuje w niej zestawienie sześciu spółgłosek obok siebie ${ }^{39}$. Ostatecznie można by założyć, że napis stanowi jedynie swego rodzaju ornament, czego potwierdzenie stanowić może fryz zakrystii kościoła św. Jakuba ${ }^{40}$. Kolejny argument popierający tę tezę to prawdopodobny sposób wykonania inskrypcji na chrzcielnicy świętojańskiej. Otóż autor owego problematycznego napisu wybrał jeden z najtrudniejszych sposobów jego wykonania - rytowanie napisu wewnątrz glinianej formy. Polegało to na drążeniu znaków przeniesionych na odbicie lustrzane, układając treść napisu od strony prawej do lewej, co dodatkowo utrudnione było ze względu na obraną przez autora technikę wybierania materiału tła w celu uzyskania wypukłych znaków $^{41}$. Przy takim połączeniu nietrudno było zapewne o pomyłkę.

Jedną z nietypowych dla wyrobu dzwonów cech zdobienia, a tym samym typowych dla chrzcielnic, jest występujące tu zdobienie w formie arkadek, wykonane ręcznie, podobnie jak inskrypcja. Takie rozwiązanie było powszechnie stosowane przy wyrobie kamiennych chrzcielnic XIII i XIV w. ${ }^{42}$

Kolejnym motywem często stosowanym przy zdobieniu chrzcielnic są dwie główki lwów umieszczone po przeciwnych stronach otoku czaszy, mające oprócz znaczenia symbolicznego znaczenie praktyczne (w główkach znajdują się otwory na pręt mający blokować przykrywę chrzcielnicy, w tym przypadku niezachowaną). Lew, podobnie jak inne fantastyczne zwierzęta typu smok czy bazyliszek, w symbolice chrztu oznacza piekielne moce. Taka symbolika wzięła swój początek z rytu chrzcielnego. Jego główny element stanowiły egzorcyzmy, których celem było oczyszczenie katechumena ze złych mocy, a tym samym przyjęcie przez niego chrztu ${ }^{43}$.

Fundując w XIII w., w dobie powszechnych kamiennych chrzcielnic, tak kosztowny pod względem materiału przedmiot jako wyposażenie pierwszego murowanego kościoła, miejscowa ludność musiała odzna-

\footnotetext{
${ }^{39}$ Ibid., s. 247.

${ }^{40}$ J. Domasłowski, op. cit., s. 156.

${ }^{41}$ M. Jakubek-Raczkowska, op. cit., s. 247.

${ }^{42}$ Ibid., s. 251.

${ }^{43}$ Ibid., s. 251-252.
} 
czać się głęboką wiarą i świadomością dotyczącą znaczenia chrzcielnicy dla parafii ${ }^{44}$.

Drugim tego typu zabytkiem jest piętnastowieczna misa znajdująca się w drugiej wielkiej i ważnej dla Torunia świątyni - w kościele św. Jakuba Apostoła. Obecnie brakuje pierwotnej podstawy ${ }^{45}$ i przykrywy ze względu na jej osadzenie w barokowej obudowie ${ }^{46}$, w której, jak się później okazało, jest umieszczona na tyle stabilnie, że dodatkowo przy dużej wadze nie było możliwe jej wyciągnięcie. Wszelkie próby podjęcia tego zadania zostały zatem zaniechane, by nie uszkodzić barokowej obudowy. Toteż niemożliwe było wykonanie pełnej dokumentacji. Z literatury znamy natomiast jej ogólny wygląa. Misa zdobiona jest na krawędzi dwoma małymi popiersiami apostołów umieszczonych po przeciwnych stronach (jest to jedyny widoczny dziś element dekoracyjny tego zabytku), które, podobnie jak w przypadku chrzcielnicy świętojańskiej (tu element ten stanowią głowy lwów), mają otwory na pręt blokujący otwarcie przykrywy chrzcielnicy. Dodatkowo misa zdobiona jest symbolami ewangelistów oraz pasem ornamentu o motywie roślinnym, kwiatowym ${ }^{47}$. Podobnie udekorowana jest również metalowa chrzcielnica pochodząca z Salzhausen w dolnej Saksonii ${ }^{48}$.

Po wewnętrznej stronie jakubowej misy dają się zauważyć liczne drobne spękania metalu powstałe zapewne przy wyrabianiu jej kształtu, brak jednak oznaczeń mogących wskazać na konkretny warsztat, w którym ją wykonano, czy rzemieślnika. Brakuje także szerszej literatury na ten temat. Nie ma ona już inskrypcji, która jest cechą łączącą misę świętojańską z warsztatem średniowiecznych dzwonów. Jednak-

\footnotetext{
${ }^{44}$ Ibid., s. 255.

${ }^{45}$ Można by jedynie spekulować na temat formy podstawy omawianej chrzcielnicy, ponieważ metalowe trzynastowieczne misy miały zazwyczaj trzy lub cztery podpory (według wzorca północnego), natomiast już w XV w. upowszechnione w odlewnictwie czasze wsparte były na trzonie i stopie (M. Jakubek-Raczkowska op. cit., s. 253), tak też mogło być i w tym przypadku. Jednakże bez styczności z zewnętrzną powierzchnią czaszy, która może przecież nosić ślady takiego łączenia, myśl ta pozostaje nadal tylko hipotezą.

${ }^{46}$ L. Kranz-Domasłowska, J. Domasłowski, Kościót świętego Jakuba w Toruniu, Toruń 2001, s. 89.

${ }^{47}$ Ibid., s. 89.

${ }^{48}$ M. Jakubek-Raczkowska, op. cit., s. 250.
} 
że pod względem formy czasze obu chrzcielnic kształtem są bardzo do siebie zbliżone (ryc. 5), przez co można by sądzić, iż misa jakubowa została wykonana przez taki sam warsztat, jednakże nieco później, bo dopiero $\mathrm{w} X \mathrm{XV}$.

Historia omawianej misy również nie jest znana. Jednym ze śladów, być może po niefortunnym wypadku, jest pęknięcie obejmujące część przykrawędną wraz z elementem zdobniczym w postaci głowy apostoła. Fragment ten został przymocowany z powrotem metalowym elementem, dziś mocno zardzewiałym. Takie uszkodzenie może świadczyć o wątpliwej jakości materiału, z którego został wykonany obiekt.

W XVI w. Torun przeszedł gruntowne przemiany religijne. Zbiegło się to $\mathrm{w}$ czasie z przemianami artystycznych gustów elit społecznych, ujawniającymi się m.in. w kościołach. Sztuka wprowadziła cechy renesansowe zgodnie z wzorem metropolii Prus Królewskich - Gdańska. Ze świątyń miast hanzeatyckich zaczęto eliminować stare średniowieczne wyposażenie. Działo się tak nie tylko z pobudek religijnych, ale głównie $\mathrm{z}$ powodu przemian smaku artystycznego. $\mathrm{Z}$ kościołów znikały głównie cenne monstrancje i relikwiarze czy stare, nieprzydatne już w liturgii oraz kosztowne w renowacji ołtarze boczne ${ }^{49}$. Protestanci, którzy przejmowali wówczas kościoły w Toruniu, doceniali dydaktyczną funkcję wyobrażeń, ograniczając ich tematykę do podstaw biblijnych i odrzucając wytwory średniowiecznej duchowości poparte prywatnymi objawieniami. Fundowano np. nowe bogato zdobione ambony, służące długim kazaniom, które były uważane za główny punkt liturgii, a przestrzeń nawową wypełniano ławami dla wiernych ze względu na zaprzestanie w tym miejscu procesji. W tym okresie zaczęto także użytkować nowe chrzcielnice ${ }^{50}$, które stanowiły dzieła sztuki ukazujące wyobrażenie o tym, jakie możliwości finansowe $\mathrm{i}$ artystyczne miało mieszczaństwo złotego wieku w historii Torunia ${ }^{51}$. Jednym $\mathrm{z}$ takich zabytków jest drewniana chrzcielnica z kościoła św.

\footnotetext{
${ }^{49}$ L. Krantz-Domasłowska, J. Domasłowski, op. cit., s. 91.

${ }^{50}$ Wówczas ustawiano chrzcielnice $\mathrm{w}$ prezbiterium, w bezpośrednim sąsiedztwie ołtarza, na osi kościoła, zob. S. Pawlak, Chrzcielnica - misa chrzcielna, anioł chrzcielny, 2009, http://www.architektura.pomorze.pl/?id=46\&PHPSESSID=a7f7633f37a0be 513c70cf23ebf7af5d [dostępne w Internecie dnia: 19.05.2013]

${ }^{51}$ Ibid., s. 92.
} 


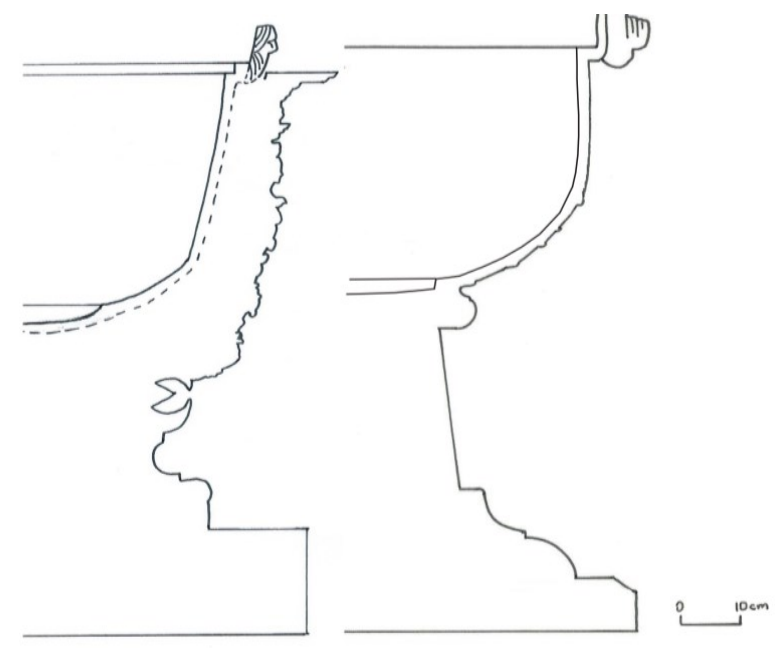

Ryc. 5. Porównanie kształtu metalowych mis chrzcielnych z kościoła św. Jakuba (po lewej) i z kościoła Świętych Janów (po prawej) (rys. M. Gajewska)

Jakuba w Toruniu (ryc. 6). Jej wykonanie datuje się na pierwszą ćwierć XVII w. Chrzcielnica zachwyca niezmiernie bogatym detalem ówczesnego warsztatu toruńskiej snycerki, na który wpływ miały cechy renesansowe wzorowane na gdańskiej metropolii. Uczyniono z niej obudowę dla wcześniejszej piętnastowiecznej misy chrzcielnej, znacznie skromniej zdobionej, która zapewne swoim wykonaniem nie zachwycała ówczesnych mieszczan. Zgodnie ze zwyczajem protestanckim chrzcielnica stanęła przy wejściu do prezbiterium. Jednakże z osiemnastowiecznych planów Fryderyka Jerzego Steinera wynika, że w latach trzydziestych, gdy kościół ponownie był świątynią katolicką, znajdowała się ona $w$ tylnej części nawy południowej ${ }^{52}$. Podobnie jak chrzcielnica z kościoła świętojańskiego, tak i ta pierwotnie miała drewnianą balustradę. Pod koniec kolejnego wieku do tego manierystycznego naczynia dodano przykrywę wykonaną już w stylu rokokowym ${ }^{53}$.

\footnotetext{
52 Ibid., s. 96

${ }^{53}$ Ibid., s. 96
} 


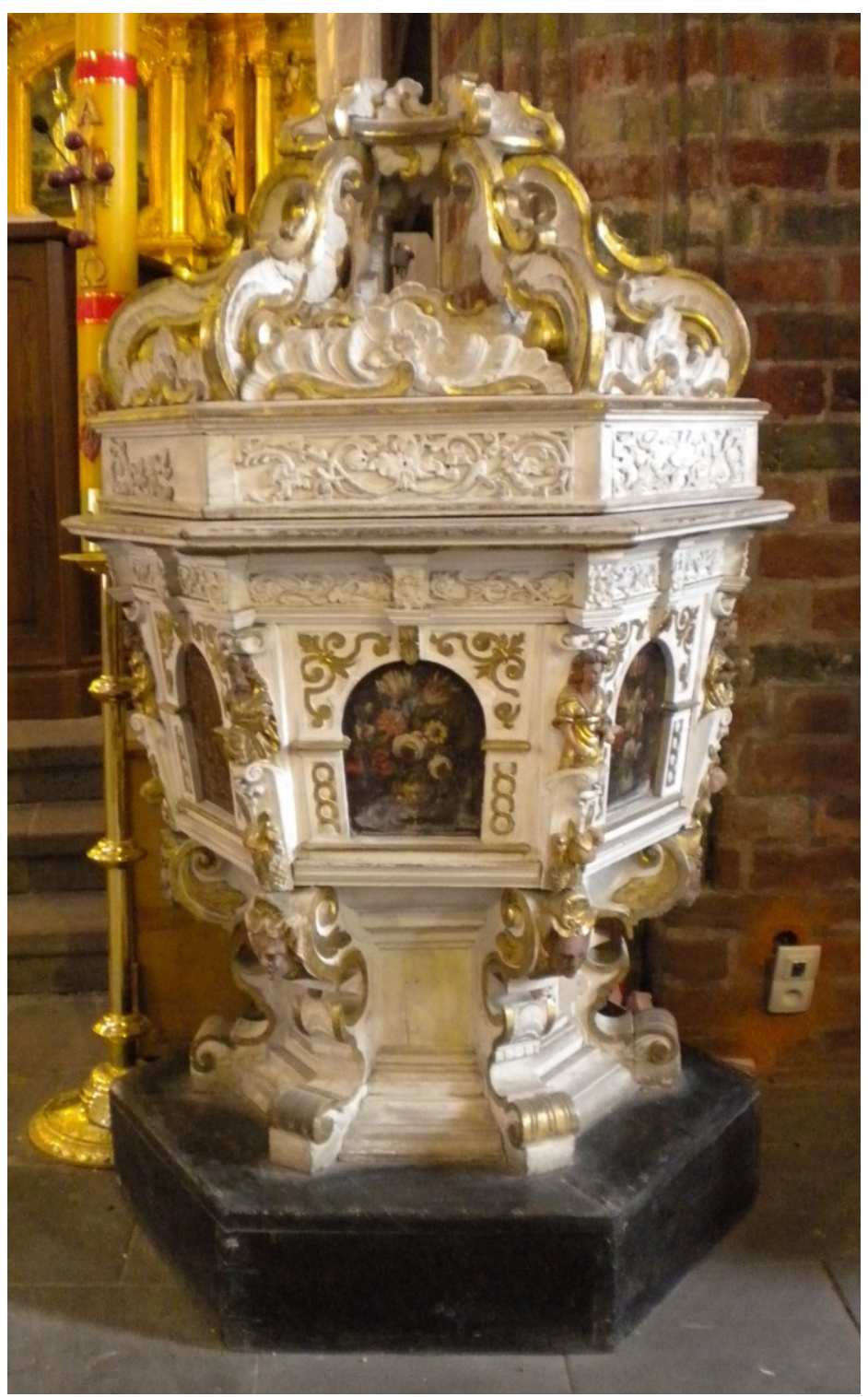

Ryc. 6. Torun, kościół św. Jakuba, chrzcielnica (fot. M. Gajewska) 
Z kolei trzy, zupełnie różniące się między sobą, drewniane barokowe chrzcielnice znamy z kościołów w Toruniu na Podgórzu, Czarnowie i Srebrnikach. Jedynym wspólnym elementem jest tutaj motyw anioła. Poza tym jednak każda $\mathrm{z}$ nich pochodzi raczej z innego warsztatu. Obiekt z kościoła Świętych Piotra i Pawła na Podgórzu w Toruniu, datowany na 1750-1760 r., jest wykonany w stylu rokoko. Zabytek ocalał z płonącego kościoła parafialnego św. Anny ${ }^{54}$. W porę został wyniesiony i dziś stoi w kościele Świętych Piotra i Pawła w prezbiterium. Był konserwowany przynajmniej dwa razy, zatem jego wygląd zapewne znacznie różni się od pierwotnego.

Innym typem chrzcielnic i kropielnic barokowych są bardzo charakterystyczne w formie zabytki wykonane $\mathrm{z}$ marmuru bądź, jak wynika z niektórych kart ewidencyjnych, ze stiuku (co wydaje się wysoce wątpliwe, biorąc po uwagę dalsze rozważania na temat ich powstania). Wszystkie te obiekty mają taką samą formę okrągłej w rzucie misy, zdobionej puklowaniem. Kropielnice są bardzo małe i nie mają podstaw, są wmurowywane w ścianę do około jednej trzeciej szerokości. W Toruniu zabytki te spotkać można w trzech kościołach: po jednej w kościele św. Jakuba i w kościele Wniebowzięcia NMP oraz dwie na Podgórzu w kościele Świętych Piotra i Pawła. W dwóch ostatnich przypadkach kropielnica ma dodatkowo osobno wykonaną półkolistą niszę z krzyżem równoramiennym w zwieńczeniu. Oprócz tego wszystkie są czarnego koloru.

Znamy również marmurowe chrzcielnice tego samego typu. W Toruniu znajdują się dwie: większa w kościele Wniebowzięcia NMP (ryc. 8), druga natomiast, mniejsza, w kościele Św. Ducha. Pierwsza została umieszczona w świątyni w czasie wyposażania kościoła w nowy barokowy wystrój. Było to po 1731 r., kiedy to protestancki dotąd kościół został przejęty przez zakon bernardynów. Bernardyni otrzymali wówczas także odszkodowanie za zniszczone paramenty kościelne, a po przejęciu kościoła zadbali o jego wyposażenie ${ }^{55}$. Pierwotnie funkcję chrzcielnicy pełniła tutaj chrzcielnica wymieniona jako druga, będąca

\footnotetext{
${ }^{54}$ J. Domasłowski, Kościót Świętych Piotra i Pawła i klasztor franciszkanów (dawniej reformatów) na Podgórzu w Toruniu, Toruń 2007, s. 82.

${ }^{55}$ K. Kluczwajd, Skarby kościoła Mariackiego w Toruniu, Torun 2005, s. 8.
} 


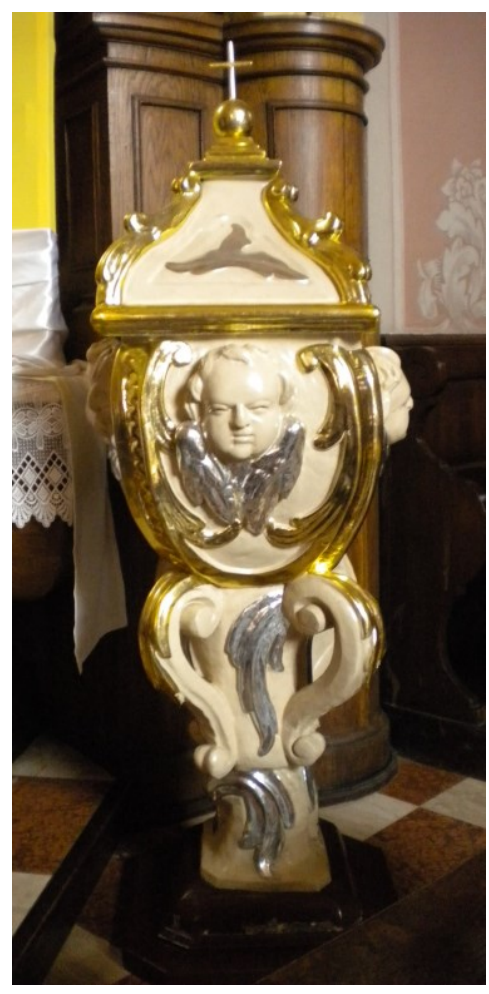

Ryc. 7. Toruń (Podgórz), kościół Świętych Piotra i Pawła, chrzcielnica (fot. M. Gajewska)

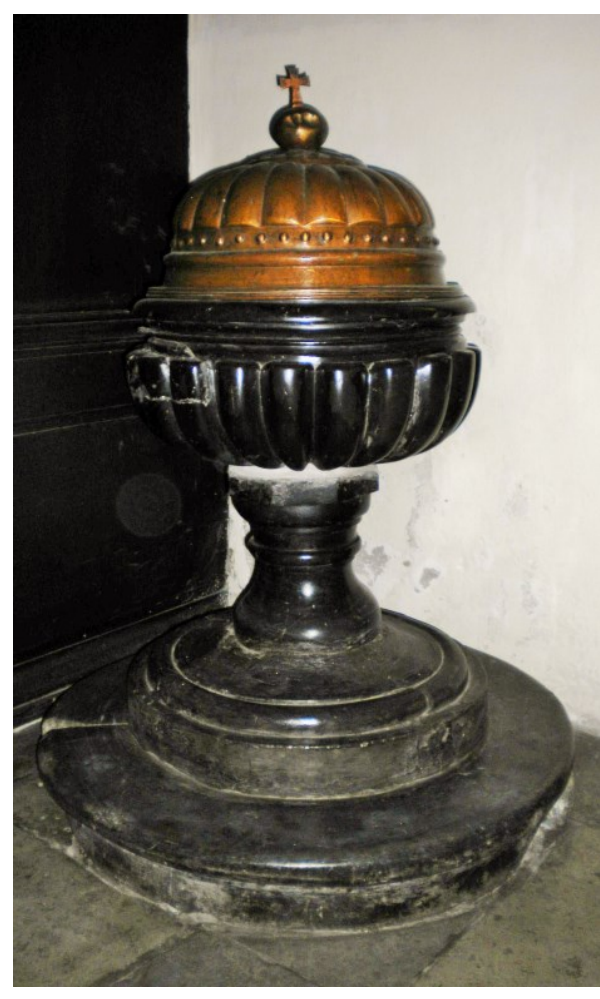

Ryc. 8. Toruń,

kościół Wniebowzięcia NMP, chrzcielnica (fot. M. Gajewska)

dziś z kolei kropielnicą w kościele Św. Ducha. W 1689 r. została ona bowiem ufundowana przez ławnika Jana Schultza dla kościoła Wniebowzięcia NMP, po odebraniu zaś kościoła protestantom bernardyni przekazali ją gminie ewangelickiej Starego Miasta ${ }^{56}$, skąd potem trafiła już ostatecznie do kościoła Św. Ducha. Warto także wspomnieć, iż pierwotnie kropielnica ta miała także przykrywę miedzianą, w części złoconą, na której widniał napis informujący o fundatorze oraz dacie

\footnotetext{
${ }^{56}$ Ibid., s. 68.
} 
powstania $^{57}$. Dziś przykrywa znajduje się w Muzeum Okręgowym w Toruniu $^{58}$

Mając na uwadze podobieństwa tych marmurowych obiektów, można by pokusić się o tezę, że mimo braku informacji dotyczących ich ufundowania, wszystkie stanowiły część tego samego etapu w historii kościołów toruńskich: mianowicie większego przedsięwzięcia zapoczątkowanego zaraz po tym, jak świątynie powróciły do rąk katolików.

\section{Podsumowanie}

Biorąc pod uwagę zbiór znanych nam dziś chrzcielnic i kropielnic kościołów parafialnych Torunia i okolic, nie można stwierdzić, że stopniowo stawały się one, poczynając od prostych form, bardziej urozmaicone, bogaciej dekorowane. Było to raczej zjawisko odwzorowywania ówczesnych trendów w sztuce niż przejaw ewolucji tychże przedmiotów. Przyglądając się z bliska tym naczyniom można zauważyć pewną zależność ich wykonania od materiału. Pierwsze, kamienne chrzcielnice w XIII i XIV-wiecznych, ówcześnie nowo wybudowanych kościołach murowanych, były jedynie polnym kamieniem z wydrążeniem na wodę święconą. Nie miały żadnych zdobień. Wyjątek stanowiły wapienne misy chrzcielne importowane z Gotlandii bądź misy na nich wzorowane. Te z kolei były już dziełem głęboko przemyślanym przez artystę, indywidualnym. Równolegle do nich powstawały także naczynia wykonane ze stopu metali, również zdobione, ale bardzo prosto. Chrzcielnice te należały do rzadkości, najpewniej ze względu na materiał, który w XIII-XIV w. był bardzo kosztowny, a także ze względu na niewielką liczbę rzemieślników posiadających umiejętność obróbki tak obszernej masy metalu, potrzebnej do wykonania misy chrzcielnej, która rozmiarami miała odpowiadać typowemu kościelnemu dzwonowi. Według Moniki Jakubek-Raczkowskiej ufundowanie tak kosztownego i prestiżowego przedmiotu pierwszemu w Toruniu mu-

\footnotetext{
${ }^{57}$ Napis na przykrywie przy górnej krawędzi: IOHANNES SCHVLTZ SCAB. SVB. Ao 1689 DEO POSTERITATI HVNC LAPIDEM SACRVM VOLVIT, zob. K. Kluczwajd, op. cit., s. 68 .

${ }^{58}$ Ibid., s. 68.
} 
rowanemu kościołowi świadczy o głębokiej świadomości mieszkańców tego miasta, jak istotnym elementem świątyni jest chrzcielnica. Jednakże, idąc tym tokiem myślenia, musielibyśmy jednocześnie uznać, iż owej świadomości nie miała ludność zamieszkująca okoliczne wsie, gdzie wyrabiano proste, niezdobione kamienne misy, wykonane $\mathrm{z}$ jednego kamienia polnego, ogólnie dostępnego, a przez to i taniego. Toruń jako duży ośrodek miejski niewątpliwie miał lepszy dostęp do wszelkiego rodzaju rzemieślników oraz do ekskluzywnego materiału, szczególnie w okresie krzyżackim, gdy trafiły tu również gotlandzkie chrzcielnice, stąd zapewne wręcz obowiązkiem było ukazanie wspaniałości wnętrza poprzez bogate wyposażenie. Świątynie w małych okolicznych miejscowościach są natomiast mniejsze, prostsze w wykonaniu, ich wyposażenie nie musiało być zatem utożsamianie ze świadomością mieszkańców, lecz ze stanem majątkowym ludności, wspólnotą kościoła.

Pozostaje natomiast jeszcze kwestia, która mogłaby być w niektórych przypadkach tożsama z tezą Moniki Jakubek-Raczkowskiej. Mianowicie chodzi o chrzcielnice, które do dnia dzisiejszego bądź się nie zachowały, bądź zostały po prostu usunięte ze świątyń na rzecz nowszych, bardziej prestiżowych. Znane są dziś bowiem kościoły wyposażone w barokowe, wykonane w XVIII w., drewniane chrzcielnice. Kościoły te są zazwyczaj datowane nie później niż na XIV w., a powstawały zwykle w momencie utworzenia parafii. Musiały zatem już wówczas znajdować się tam chrzcielnice, które zapewne miały cechy typowe dla ówczesnej epoki. Brak jednak jakichkolwiek wzmianek na ich temat w literaturze. Czy mógł to być zatem przejaw braku świadomości, jak ważnym elementem wyposażenia kościoła parafialnego jest chrzcielnica? Być może traktowano ją jako zwykłe naczynie, przedmiot, który po latach, ze względu na nowe trendy, można uznać za nieatrakcyjny i po prostu się go pozbyć? Przecież, jak to ujął w swoim artykule Sławomir Pawlak: „obok ołtarza i ambony, stanowiła [chrzcielnica] najistotniejszy element wyposażenia każdego kościoła" ${ }^{\text {"59. Tak }}$ więc takie potraktowanie ważnego z punktu widzenia wspólnoty ko-

\footnotetext{
${ }^{59} \mathrm{http}: / /$ www.architektura.pomorze.pl/?id=46\&PHPSESSID=a7f7633f37a0be513 c70cf23ebf7af5d [dostęp: 19.05.2013].
} 
ścioła przedmiotu byłoby zapewne czymś niedopuszczalnym. Jednak dziś podziwiać możemy chrzcielnice drewniane, wykonane w duchu baroku, odznaczające się bogatym, przykuwającym wzrok zdobnictwem, co zapewne miało zachęcać wiernych do uczestniczenia w nabożeństwach bądź też przyciągać nowych członków wspólnoty chrześcijańskiej.

Nie zawsze jednak stare kamienne chrzcielnice były zapominane. Praktykowano również zwyczaj nadawania im „drugiego życia”, umieszczając w kruchtach jako kropielnice.

To samo dotyczy kwestii umiejscowienia chrzcielnicy w kościele. Pierwotnie, według symboliki, umieszczano ją w głównym wejściu do świątyni, by nowy parafianin poprzez chrzest mógł stać się członkiem wspólnoty i mieć wstęp do dalszej części kościoła. Tuż po przejęciu kościołów przez protestantów chrzcielnicę przesunięto do prezbiterium, by tam tworzyła jedną oś z ołtarzem i amboną. Jednakże po przywróceniu świątyń katolikom chrzcielnice dekanatu toruńskiego nie wróciły na swoje miejsca. Taka sytuacja $\mathrm{w}$ jakiejś części pozbawia chrzest święty symboliki na rzecz ukazania prestiżu kościoła, być może też miało to na celu zwrócenie całej uwagi wiernego na sferę sacrum świątyni - na prezbiterium. 